\title{
The Use of Low-Order and Higher-Order Questions in Mathematics Teaching: Video Analyses Case Study
}

\author{
Masitah Shahrill (Corresponding author) \& Lawrence Mundia \\ Sultan Hassanal Bolkiah Institute of Education \\ Universiti Brunei Darussalam \\ Jalan Tungku Link, Gadong BE 1410, Bandar Seri Begawan, Brunei Darussalam \\ E-mail: masitah.shahrill@ubd.edu.bn
}

Received: March 19, 2014 Accepted: March 30, 2014 Published: May 1, 2014

doi:10.5296/jse.v4i2.5318 URL: http://dx.doi.org/10.5296/jse.v4i2.5318

\begin{abstract}
The aim of this video analyses case study was to compare levels of teacher questioning in mathematics classrooms between two countries (United States and Australia) whose language and mode of classroom instruction is English. Data were collected by analysing the video lessons from the United States and Australia in the Learner's Perspective Study. Descriptive statistics were used to analyse the data. The findings revealed that in both the United States and Australia, male students were more engaged in questions posed by their teachers as compared to the female students. The overall results showed that male students volunteered, and were called on more to teachers' questions compared to the female students. There were similarities and differences observed and the striking similarity was the frequently asked low-level questions in the lessons. Furthermore, male students were asked more high level and low level questions compared to the female students. In contrast, there were more students in Australia than in the United States who were asked more than two high and low level questions. The data in this study suggest that gender biased teacher questioning do occur in the Year 8 mathematics classes.
\end{abstract}

Keywords: Teacher questions, low and high level questions, Mathematics lessons 


\section{Introduction}

Questioning is seen as a way of generating the kind of talk and communication that can lead to learning. Many educators use questions and answers as an instructional strategy. To be beneficial, however, this teaching method requires the users (both teachers and students) to demonstrate clarity of expression and effective exposition of points. Weimer (1993) suggests that multi-way questions (from the teacher-to-students and student-to-student) should be used carefully so that they are not intimidating and make learners think critically. In addition, Weimer (1993) says that students should be given enough time to reflect before responding and that wrong answers should be handled constructively. Recent research indicates that these points are crucial and important in situations where disabled learners are integrated in inclusive classrooms (Mundia, 2009) and in classrooms with a lot of repeaters or less-able learners (Mundia, 2010a). Research by Bradshaw and Mundia (2006) and Haq and Mundia (2012) found that student teachers being prepared for inclusive schools often had a lot of concerns about how to handle disabled students which included interacting with them properly. The trainee teachers eventually graduate and go on to serve as teachers with their deficits and concerns. Trainee teachers' low self-efficacy in implementing inclusive education practices was still a source of concern for teacher educators (see Tait \& Mundia, 2014). Using questions as part of a tool in teaching is without doubt a good strategy that motivates and challenges students' thinking and learning processes and that may lead to classroom interaction. Additionally, previous research shows that the students' asking of questions might generally be regarded as "a useful process in their pursuit of learning in that questioning is one of the most important ways students can support their own learning to become literate, well-educated people” (Boaler \& Humphreys, 2005, p. 72). To be effective, however, the questions used (both oral and written) should be stated or phrased in a simple and friendly manner. Evidence from research on learning styles and study strategies of students from a developing country who speak English as a second language demonstrates the significance of using language properly in exposition and questioning (see Shahrill et al., 2013). These researchers found that the successful students in mathematics depended largely on language-based expressive learning styles and study strategies such as speaking, writing, and reading (Shahrill et al., 2013). This implied that questions that are hard, tricky or confusing were likely to lower students' interest and motivation to learn and this was more evident in young learners (Mundia, 2007; Mundia, 2012a). There was also evidence from another study that the learning styles and study strategies used affected the students' test anxiety and attributions (for success and failure) in different ways (Matzin et al., 2013). For example, high achievers in mathematics tended to score low on test anxiety possibly due to their mastery of the language of instruction. Furthermore, there is another recent study which showed that weak students in mathematics often have mathematics anxiety (Hamid et al., 2013). To reduce students' mathematics anxiety, these researchers suggested modifying or innovating instructional methods and assessment strategies (including the way students were questioned verbally and through written tests).

Martino and Maher (1994) stated that the type of teacher question has to be connected to students' present thinking, enabling the teacher to acquire the students' current thinking of the 
mathematical idea. It is essential at the end of the discussion that the teacher gives feedback because students need to be assured that they have mastered the mathematics problem. Unfortunately, the common strategy that teachers employ is to ask students closed questions that have only a simple correct answer followed by teachers' praises. Researchers such as Rowe (1974), Wilen and Clegg (1986), Wilen (1991), Ellis (1993) and Rose and Litcher (1998) claimed that in order to increase student learning and foster student high achievement, teachers should ask questions at all levels (high-level and low-level questioning). Students' learning gains increase as the variety of types of teacher questions increase. Wimer, Ridenour, Thomas and Place (2001) stated that "Higher level and lower level questions have their place in the classroom; vigilant teachers employ both types when the need arises" (p. 91). Furthermore, Gall and Rhody (1987) have also recommended the use of both lower level and higher cognitive questions. In situations where serving teachers lack effective questioning skills, continuous professional development (CPD) workshops would be highly recommended. Alternatively, serving teachers who are less competent or proficient in questioning skills could benefit, via cooperative teaching, from colleagues who are good at this skill. According to Mahalle et al. (2014), collaboration of this nature might best be possible in environments where teachers have high interpersonal trust. Team teaching by instructors of the same gender or different genders is one good way teachers would cope with stressful teaching tasks (see Mundia, 2010c; Haq \& Mundia, 2013). However and depending on the problem and the skill needs assessment of teachers, a reform of the whole national curriculum would sometimes be necessary and beneficial. For example, the curriculum reforms introduced by Brunei Darussalam known as the National Education System for the 21st Century or SPN 21 - Sistem Pendidikan Negara Abad Ke-21, in Bahasa Melayu language (see Mundia, 2010b) were partly intended to address teacher skill deficits including questioning strategies. In instances where teacher skill deficits are many and warrant it, a reform of the whole teacher education system would then be appropriate (e.g. see Mundia, 2012b; Mundia, 2012c; Tait \& Mundia, 2012) in addition to reforming the curriculum and instructional methods (see Mundia, 2010b). According to Tait and Mundia (2014) such initiatives would be important in enabling teachers to raise their self-efficacy in implementing new teaching skills or strategies especially in inclusive education settings. Asking appropriate questions (both verbal and written) is one way teachers could help students, especially those with high support needs, to resolve their learning difficulties. A recent study by Shahrill and Mundia (2014) based on international students in Australia found that many learners in a foreign context did not know how to cope effectively with their learning and social problems.

Teacher questioning has also been linked to the effects on classroom interactions and the performance of boys and girls in mathematics lesson. Teachers do ask boys more questions than they ask girls, especially questions that involve academic content (Sadker \& Sadker, 1994). A meta-analysis review by Kelly (1988) has confirmed that girls received less of teacher's attention in class and boys received more of all kinds of classroom interaction; more instructional contacts, more high-level questions, more academic criticism, more feedback and more teacher praises. Furthermore, Kelly concluded that both boys and girls are likely to give voluntary answers in class but boys are more likely to call out the answers. When teachers were made aware of the gender-biased interactions in classroom, nothing improved 
(Gould, 1995). Hendrick and Stange (1989) stated that although teachers don't show gender favouritism on a conscious level, they tend to exhibit in it in a subtle approach used with their students.

\subsection{International Video-Based Classroom Studies}

The advent of video recording of classroom lessons has opened up new possibilities for the study of classroom teaching and learning (Ainley, 2007). Video-based studies are expected to have the greatest potential to inform classroom practice because of its ability to sustain and its capacity to capture the complexities of a classroom, and subsequently, conduct multiple analyses of classroom teaching by connecting classroom practice and consequent learning from multiple perspectives (Clarke, 2003; Fitzgerald, Hackling \& Dawson, 2013).

For international comparative research studies in education, in particular, the use of video technology as a methodological tool has become increasingly popular. This is mainly because the use of video technology provides a powerful lens to view and record classroom practices in very distant parts all over the world (Hiebert et al., 2003; Jacobs, Hollingsworth \& Givvin, 2007; Savola, 2008; Ulewicz \& Beatty, 2001). The TIMSS 1995 and 1999 video studies (Hiebert et al., 2003; Jacobs et al., 2003; Stigler et al., 1999) and the Learner's Perspective Study (LPS) project (Clarke, Emanuelsson, Jablonka \& Mok, 2006a, 2006b; Clarke, Keitel \& Shimizu, 2006; Shimizu, Kaur, Huang \& Clarke, 2010) used video technologies as their main approach to generating data in mathematics classroom teaching and learning at the lower secondary level, specifically Year 8 mathematics classrooms.

The LPS project is a well-known international classroom study that examines, with a more in-depth approach, sequences of at least ten consecutive Year 8 mathematics lessons with the use of video technology. The mathematics teachers from each participating country in the LPS project were identified for their locally-defined 'teaching competence'. While in the TIMSS video studies, only single lessons from one teacher in randomly selected classrooms were recorded with the teachers portrayed as being typical or average. The LPS project did not report the results of their analyses in a manner similar to the TIMSS video studies. Their mission was to conduct and present complementary analyses of the shared LPS data and to inform classroom practice in different multiple ways. Furthermore, the project was not designed to challenge the TIMSS video studies; rather it was to complement those studies (Clarke, Emanuelsson et al., 2006b).

\subsection{Comparative Studies on Teachers' Questioning from Video Lessons}

To date, there had been two comparative studies on teachers' questioning from video lessons. Each study used specifically the data available from the TIMSS 1995 video study and the LPS project. Kawanaka and Stigler (1999) investigated teachers' use of questions in eighth-grade mathematics classrooms in Germany, Japan and the United States. They explored the patterns of discourse by focusing on teachers and students talk during lessons (Study 1) as well as the teachers' use of higher order questions in the classrooms (Study 2). In Study 1, a total of 231 video recorded lessons, 100 German, 50 Japanese and 81 US lessons were used, while in Study 2, 30 randomly selected video recorded lessons from each country 
were analysed. However from their analyses, not all the 30 lessons contained higher order questions they categorised as requesting descriptions or explanations. Lessons that had them portrayed teachers in the three countries asked different kinds of higher order questions related to lesson activities that occurred at particular times during particular events in the lessons.

Meanwhile, Koizumi's (2013) study was part of the LPS project that explored the similarities and differences in teachers' questioning from German and Japanese mathematics classrooms by specifically focusing at the stage of introducing new mathematical content. Based on Koizumi's findings, the role of questions that previous studies regarded as lower cognitive questions, such as recalling previously learned material, was seen as important especially at the stage of introducing new content materials. Since the lessons recorded were sequences of consecutive lessons, Koizumi also found patterns in the teachers' questioning that repeatedly emerged from connecting the previous to the subsequent lessons.

Both comparative studies mentioned above analysed their data using video recorded lessons although the approach in collecting the data was distinctively different. In this study, the author used the LPS data collected from the United States and Australia, with permission granted from respective key persons, to analyse teachers' questioning in video recorded mathematics classrooms. However the approach taken in deciding which lessons to be observed will be different and this will be explained later in this paper. It should also be noted that the authors are not in any way associated with the LPS project, but had used the LPS project data collection approach in the first author's doctoral research study (refer to Shahrill, 2009).

\subsection{Purpose of Study}

The aim of this video analyses case study is to compare the levels of teacher questioning between two countries which superficially poses similar cultures and whose language and mode of classroom instruction is English. The two countries are United States and Australia. The research questions investigated are as follows:

1. What type of questions (low-level or higher-level) did the teachers pose to their students?

2. What styles of teacher questioning did the teachers use in the lessons?

The styles of teacher questioning will explicitly focus on students volunteering to give the answers to the teacher, or the teacher expecting the answer to be given by him or her calling out his or her students' name.

Furthermore, the differences and similarities in the styles and types of teacher questioning will be explored and with the help of frequency counts in comparing gender differences with respect to student responses to teachers' high-level and low-level questions. The reason for doing a gender comparison study is to investigate which gender gets questioned more and how this may influence the students' mathematics achievement. Additional investigation on teacher's allocation of wait time and teachers' use of praises or motivating words in their 
students' response to a question is also explored in this study.

\section{Method}

We describe briefly the approach that we used in conducting the present study. The methodology adopted was technology-mediated.

\subsection{Design}

This was basically a qualitative study of Year 8 mathematics lessons videotaped in US and Australia, two developed countries. The specific technical name for the strategy that we employed in investigating our research topic is referred to as secondary data analysis. Our primary interest and objective were to compare the questioning styles used by teachers in the observed lessons. The main advantage of the method we used was that videotaped data were readily available. The major disadvantage was that we could not determine the quality of that data by ourselves (although we were assured by the suppliers that the data were reliable and valid).

\subsection{Procedures}

Permission was sought from the Director of the International Centre for Classroom Research (hereafter, referred to as ICCR) at the University of Melbourne, Melbourne, Australia to analyze the mathematics video lessons from the US and Australia's LPS data. In the LPS data the three US schools was coded as US1, US2 and US3 and similarly for the three Australian schools were coded as AU1, AU2 and AU3. There were ten single video lessons in each of the US and Australian schools. Following ICCR's Ethical Data Access Confidentiality Rules, it is important to note that the names of the schools, teachers and students that had been recorded for this analysis will not be released and mentioned in this study.

\subsection{Sample}

In total, six different teachers (one in each of the six selected schools) were observed via videotapes, two male and four female teachers. Although the same teacher was observed in ten single video lessons at each school, the class, students, topics covered, and instructional approaches were different for each lesson taught. Each single video lesson ranged from 50 to 70 minutes up to an hour and a half in length. The class video of the teachers and students together with the transcripts were available only within the ICCR premise. Due to constraints in the accessibility of the available data and also of time, the authors then decided to analyze only three schools from each country and limited the observation to the first lesson of each school. For the entire observation, the Mixed Video Lessons (comprised of two different video lesson footages of the teacher and the students displayed together on the screen) were mainly used in the analyses. On a few occasions, the Student Video Lessons (video lesson footage of the students only) was also analyzed. During all observations, only field notes were taken for the analyses.

The students studied within the LPS data were six Year 8 mathematics classes. There were a total of 85 students (44 male and 41 female students) from the US schools and in the Australian schools, 57 students (34 male and 23 female students). The three US and 
Australian schools were in demographically different regions of the same major US and Australian city respectively (Mesiti \& Clarke, 2003). All the classes in this study consisted of mixed gender students. Table 1 shows the description of the codes for each school and the respective classes.

Table 1. Details of the analysed schools in US and Australia

\begin{tabular}{lcccrrr}
\hline Country & $\begin{array}{c}\text { Year } \\
\text { level }\end{array}$ & $\begin{array}{c}\text { Teacher } \\
\text { gender }\end{array}$ & $\begin{array}{c}\text { Teacher } \\
\text { code }\end{array}$ & $\begin{array}{c}\text { No. of male } \\
\text { students }\end{array}$ & $\begin{array}{c}\text { No. of female } \\
\text { students }\end{array}$ & $\begin{array}{c}\text { Total no. of } \\
\text { students in } \\
\text { class }\end{array}$ \\
\hline \multirow{3}{*}{ USA } & 8 & Male & TUS1 & 13 & 11 & 24 \\
& 8 & Female & TUS2 & 13 & 19 & 32 \\
& 8 & Female & TUS3 & 18 & 11 & 29 \\
\multirow{3}{*}{ Australia } & 8 & Female & TAU1 & 12 & 12 & 24 \\
& 8 & Female & TAU2 & 14 & 6 & 20 \\
& 8 & Male & TAU3 & 6 & 4 & 10 \\
\hline
\end{tabular}

\subsection{Data Collection}

During the observation, whenever a student answered a Teacher Question, student's answering procedure was identified as Volunteered Answers (VA) or Teachers' Use of Students' Name (SN) and their names and gender were recorded. Recording students' names assisted in identifying which gender gave more voluntary answers and who were called out more by the teachers to answer his/her question. All the questions that came from the teachers were recorded and it was during the analysis that distinctions were made whether it was a low-level or high-level question. A low-level teacher question (LLQ) was identified as closed question that required students to give a simple correct answer, for example, "What is the perimeter of the object?” In contrast, a high-level teacher question (HLQ) required students to think critically, particularly when the student was encouraged to clarify, explain and support his/her response, for example, "More importantly, how did you get that answer? (Questions depicted from TUS1).

Wimer and colleague (2001) based the rationale of their data collection on the following assumptions, which were also considered for this study. The teacher controls the discussion and questioning within the class. It is the teacher who determines which students will be called on. The teacher decides whether follow-up questions will be asked. For this study, the authors also considered that student response was of interest and the focus was on which code (VA or SN) fitted the teachers' questions. Not all of the schools observed portrayed the categories of the research questions that were anticipated for this study. For example, two schools from the US data, the lessons were mostly doing exercises either from the overhead projectors or working in groups. The teachers then walked between desks to help out individual groups or students. When this happened the conversation wasn't picked up in the 
voice recording nor was it displayed in the transcripts. Therefore, not much could be analyzed from these two US schools (US2 and US3).

The quality of our data analysis was assessed by inter-coder agreement percentage reliability (85\%) which was based on the two researchers. In addition, our obtained categories have good social validity in that they can be applied directly in US, Australian and other country's educational contexts.

\subsection{Data Analysis}

Data from the videotaped lessons were analyzed qualitatively using techniques such as content analysis and constant comparison (Lincoln \& Guba, 1985; Patton, 1990) to generate categories, themes, and quotations. We then assigned frequencies and percentages to categories and presented these pictorially or visually through figures.

\section{Results of the Study}

It was observed that in both countries, only a quarter of the total questions posed to students were high-level questions (HLQ). Table 2 shows the frequency counts of the total number of high-level and low-level teacher questions for the three classes in the US and Australia. Of the 76 US teacher questions, 60 of them were low-level questions (LLQ), whereas 62 LLQ out of the 85 Australian teacher questions was recorded. US schools asks more low-level questions (78.9\%) compared to Australian schools (72.9\%) but it was the opposite for high-level questioning with each comparison of an approximately $6 \%$ difference.

Table 2. The total number of high-level and low-level teacher questions posed to students for the US and Australia schools

\begin{tabular}{lrrlrr}
\hline & HLQ & LLQ & & HLQ & LLQ \\
\cline { 2 - 3 } School & $n$ & $n$ & School & $n$ & $n$ \\
\hline US1 & 9 & 36 & AU1 & 14 & 13 \\
US2 & 7 & 12 & AU2 & 9 & 24 \\
US3 & 0 & 12 & AU3 & 0 & 25 \\
\hline US Total & $16(21.1 \%)$ & $60(78.9 \%)$ & Au Total & $23(27.1 \%)$ & $62(72.9 \%)$ \\
\hline
\end{tabular}

The schools that engaged more in teacher questioning were US1 and AU2. AU1 was the only school that has a fair share of HLQ and LLQ. US3 and AU3 with 12 and 25 LLQ respectively were the two schools with the least low-level teacher questions. The reason for this was because US3 lesson was mostly seatwork and group work. The questions that the teacher (TUS3) asked were mostly, “Any questions from homework?” "Anybody got a different answer?” Students mainly discussed their work within the group. It was a different case for AU3 lesson, the teacher (TAU3) was faced with most of the students being absent from the lesson. TAU3 had no choice but to amend the lesson to a previous lesson review. TAU3 was mainly asking students to give the answers to the written exercises. Table 3 provides the data for comparing which student gender were asked more or less HLQ and LLQ in both the 
countries.

Table 3. US and AU students to whom teachers directed HLQ \& LLQ during mathematics lessons

\begin{tabular}{|c|c|c|c|c|c|}
\hline \multirow[b]{2}{*}{ Gender } & \multicolumn{4}{|c|}{ Number of questions asked } & \multirow{2}{*}{$\begin{array}{l}\text { Total number of US/AU } \\
\text { students who asked questions }\end{array}$} \\
\hline & 0 & 1 & 2 & $3+$ & \\
\hline \multicolumn{6}{|c|}{ High-Level Questions (HLQ) } \\
\hline US Male $(n=44)$ & 35 & 7 & 1 & 1 & 9 \\
\hline US Female $(n=41)$ & 37 & 4 & 0 & 0 & 4 \\
\hline US Total $(N=85)$ & 72 & 11 & 1 & 1 & 13 \\
\hline \multicolumn{6}{|c|}{ Low-Level Questions (LLQ) } \\
\hline US Male $(n=44)$ & 23 & 13 & 5 & 3 & 21 \\
\hline US Female $(n=41)$ & 24 & 13 & 3 & 1 & 17 \\
\hline US Total $(N=85)$ & 47 & 26 & 8 & 4 & 38 \\
\hline \multicolumn{6}{|c|}{ High-Level Questions (HLQ) } \\
\hline AU Male $(n=34)$ & 23 & 7 & 3 & 1 & 11 \\
\hline AU Female $(n=23)$ & 16 & 7 & 0 & 0 & 7 \\
\hline AU Total $(N=57)$ & 39 & 14 & 3 & 1 & 18 \\
\hline \multicolumn{6}{|c|}{ Low-Level Questions (LLQ) } \\
\hline AU Male $(n=34)$ & 7 & 12 & 13 & 2 & 27 \\
\hline AU Female $(n=23)$ & 11 & 7 & 4 & 1 & 12 \\
\hline AU Total $(N=57)$ & 18 & 19 & 17 & 3 & 39 \\
\hline
\end{tabular}

The similarities for both countries were noted as:

(i) The infrequent times HLQ was asked, 13 students (15.3\%) in US and 18 students (31.6\%) in Australia.

(ii) The male students were asked more HLQ and LLQ compared to the female students.

(iii) Female students were asked only one HLQ, no students were asked more than one high-level questions.

And the differences in both countries were:

(i) Less than half of the US students were asked LLQ but more than half, that is, 39 Australian students (68.4\%) were asked LLQ.

(ii) In US, 90.2\% ( $n=37)$ of the female students were asked none HLQ compared to 79.5\% $(n=35)$ male students, whereas in Australia, 69.6\% $(n=16)$ of the female students avoided teachers' HLQ compared to $67.6 \%(n=23)$ male students.

(iii) There were more students in Australia than US who were asked more than two HLQ and LLQ.

Figure 1 show the proportion of high-level and low-level questions asked of male and female 
students for US and Australia schools respectively. The figure provides clear patterns for US and Australian male and female students to whom teachers directed none or at least one HLQ and LLQ.

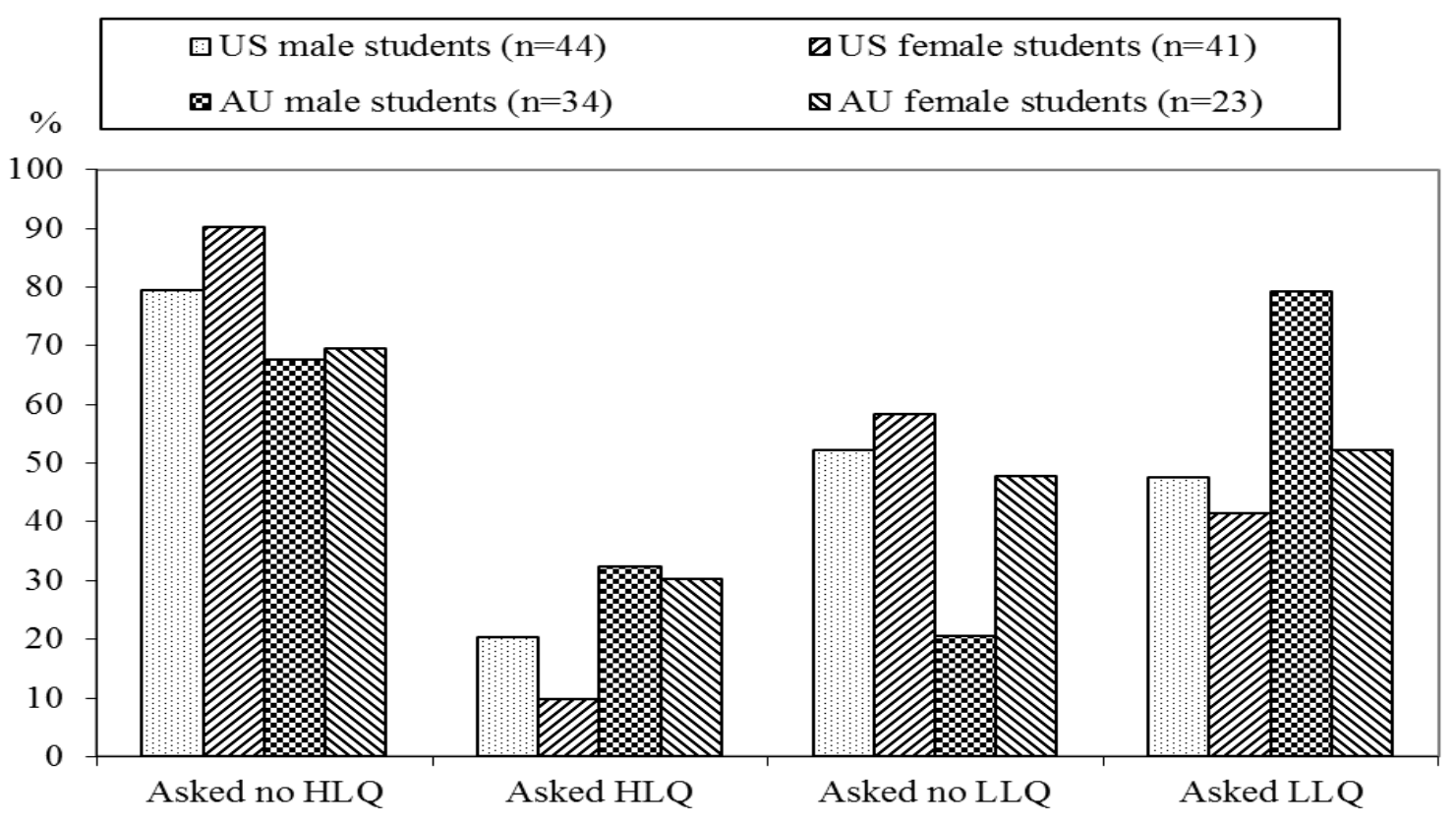

Figure 1. US and Australian students not asked and asked HLQ and LLQ

The proportion of HLQ to none HLQ for all students in Australian schools (a 32\% to 68\% ratio) was similar to the ratio within each gender group. For Australian male students the ratio was $32 \%$ to $68 \%$ and for the female students the ratio was $30 \%$ to $70 \%$. This doesn't seem to be the case for US schools, however, both US and Australian schools indicated that much less than half the overall students (US 15.3\% and AU 31.6\%) were asked at least one high-level question. The same pattern can be seen in US schools where the proportion of LLQ and none LLQ for all students was similar to the ratio within each gender group (the total was $45 \%$ to $55 \%$, for male students $48 \%$ to $52 \%$ and for female students $42 \%$ to $59 \%$ ). Australian teachers asked at least one LLQ to more than half the overall Australian students $(n=39$, $68 \%$ ), whereas US teachers have engaged at least one LLQ to only less than half of the overall US students $(n=38,45 \%)$. Furthermore, there were more female students who were not asked HLQ and LLQ compared to the male students for both countries. However, more US and Australian male students were asked HLQ and LLQ.

The overall total of student responses to high-level and low-level teacher questions is presented in Table 4. To explain further, in US schools, there were nine responses to teachers' high-level question by means of voluntary answers (either students raising their hand to answer or students calling out the answer). When teachers called out the students' name to answer his/her high-level questions, seven student responses was recorded. Note that the data in Table 4 corresponds to students' responses, and not how many students; therefore more than one student could respond either by VA or SN to the teachers' HLQ or LLQ. 


\section{Macrothink}

Journal of Studies in Education

ISSN 2162-6952

2014, Vol. 4, No. 2

Table 4. Students' responses by volunteered answering (VA) or by teachers' use of students' name (SN) of high-level and low-level teacher questions for US and Australia schools

\begin{tabular}{|c|c|c|c|c|}
\hline & \multicolumn{2}{|c|}{ HLQ } & \multicolumn{2}{|c|}{ LLQ } \\
\hline School & $\begin{array}{r}\text { Volunteered } \\
\text { Answers } \\
(\mathrm{VA})\end{array}$ & $\begin{array}{l}\text { Teachers use of } \\
\text { students' name } \\
\text { (SN) }\end{array}$ & $\begin{array}{r}\text { Volunteered } \\
\text { Answers } \\
(\mathrm{VA})\end{array}$ & $\begin{array}{r}\text { Teachers use of } \\
\text { students' name (SN) }\end{array}$ \\
\hline US1 & 6 & 3 & 6 & 30 \\
\hline US2 & 3 & 4 & 0 & 12 \\
\hline US3 & 0 & 0 & 11 & 1 \\
\hline US Total & 9 & 7 & 17 & 43 \\
\hline AU1 & 5 & 9 & 5 & 8 \\
\hline AU2 & 1 & 8 & 0 & 24 \\
\hline AU3 & 0 & 0 & 1 & 24 \\
\hline AU Total & 6 & 17 & 6 & 56 \\
\hline
\end{tabular}

In Table 5, the number of male and female students in US and Australia who answered teachers' HLQ and LLQ with respect to VA and SN are given. Of the 13 US students answering HLQ, 7 students volunteered to answer the HLQ and 6 students not volunteering (teachers calling out students' names). Subsequently, Australian teachers opted more in the use of 13 students' name (72.2\%). In answering Teachers' low-level questions, the same pattern emerged for US and Australia where most of the students' responses were recorded using SN; 27 US students (65.9\%) and 36 Australian students (87.8\%). One might predict that if teachers asked low-level questions, it should result in simple, easy and direct answers and producing more students volunteering. The results shown here have proved otherwise. 
Table 5. Frequency of US and Australian Students Answering HLQ and LLQ by VA or SN

\begin{tabular}{|c|c|c|c|c|c|c|c|c|c|c|}
\hline \multirow[b]{3}{*}{ Gender } & \multicolumn{5}{|c|}{ US students answering HLQ } & \multicolumn{5}{|c|}{ US students answering LLQ } \\
\hline & \multicolumn{2}{|c|}{ (VA) } & \multicolumn{2}{|c|}{$(\mathrm{SN})$} & \multirow{2}{*}{$\begin{array}{c}\text { Total } \\
N\end{array}$} & \multicolumn{2}{|c|}{ (VA) } & \multicolumn{2}{|c|}{$(\mathrm{SN})$} & \multirow{2}{*}{$\begin{array}{c}\text { Total } \\
N\end{array}$} \\
\hline & $n$ & $\%$ & $n$ & $\%$ & & $n$ & $\%$ & $n$ & $\%$ & \\
\hline Male & 5 & 55.6 & 4 & 44.4 & 9 & 9 & 37.5 & 15 & 62.5 & $21(24)$ \\
\hline Female & 2 & 50.0 & 2 & 50.0 & 4 & 5 & 29.4 & 12 & 70.6 & 17 \\
\hline \multirow[t]{3}{*}{ Total } & 7 & 53.8 & 6 & 46.2 & 13 & 14 & 34.1 & 27 & 65.9 & $38(41)$ \\
\hline & \multicolumn{5}{|c|}{ AU students answering HLQ } & \multicolumn{5}{|c|}{ AU students answering LLQ } \\
\hline & \multicolumn{2}{|c|}{ (VA) } & \multicolumn{2}{|c|}{$(\mathrm{SN})$} & Total & \multicolumn{2}{|c|}{ (VA) } & \multicolumn{2}{|c|}{$(\mathrm{SN})$} & Total \\
\hline Gender & $n$ & $\%$ & $n$ & $\%$ & $N$ & $n$ & $\%$ & $n$ & $\%$ & $N$ \\
\hline Male & 2 & 18.2 & 9 & 81.8 & 11 & 5 & 17.2 & 24 & 82.8 & 27 (29) \\
\hline Female & 3 & 42.9 & 4 & 57.1 & 7 & 0 & 0 & 12 & 100.0 & 12 \\
\hline Total & 5 & 27.8 & 13 & 72.2 & 18 & 5 & 12.2 & 36 & 87.8 & $39(41)$ \\
\hline
\end{tabular}

Note:

- The row total for US students answering LLQ does not add up because 3 of the US male students were represented in both groups. In other words, they gave voluntary answers and responded to their teachers calling out the names. An actual 38 students answered the LLQ; there were an actual total of 41 responses to LLQ.

- The row total for Australian students answering LLQ does not add up because 2 of the Australian male students were represented in both groups. In other words, they gave voluntary answers and responded to their teachers calling out the names. An actual 39 students answered the LLQ; there were an actual total of 41 responses to LLQ.

With respect to teachers' high-level questions (HLQ), 55.6\% of the US male students gave more voluntary answers compared to $18.2 \%$ of the Australian male students. However, Australian male students are called on more by their teachers (81.8\%). The female students in US and Australia were more likely to either volunteer or be called on. From Table 5 also, US male and female students volunteered more to teachers' LLQ (37.5\% and 29.4\%). The Australian female students gave no voluntary answers because all of them responded to the teachers' LLQ by their teachers calling out their names.

In comparing US and Australian data, the overall result (HLQ and LLQ inclusive) shows that Australian teachers preferred to use students' name to answer their questions and US students gave more voluntary answers compared to Australian students. US male students volunteered more to teacher questioning and female students were called on more by the teachers. The reverse is true for the Australian data, more VA female students and more SN for the Australian male students. With respect to both countries, male students gave more voluntary answers (VA) and were called on more often (SN).

\section{Discussion}

Research shows that teachers mostly asked their students low-level questions in class (Suydam, 1985; Wilkinson \& Martino, 1993; Wilen, 1991; Ellis, 1993; Wimer et. al, 2001). 
Suydam's (1985) research report stated that large numbers of US teachers teaching mathematics spent up to one-third of the lesson asking questions; however, 80 percent of the questions asked were at the knowledge and comprehension levels, that is, the lowest cognitive levels. The results of this study where high-level teacher questions were asked infrequently in most mathematics lessons (the overall US and Australian schools HLQ to LLQ total scores ratio are; HLQ : LLQ $=39: 122=24.2 \%: 75.8 \%$ ) supports findings from Suydam and other researchers. These results indicate that teachers should be concerned that their questioning behaviours will have an impact on student learning outcomes, particularly on students' achievement and their attitudes towards the subject (Wilen, 1991). It should be emphasised to US and Australian teachers that high-level questions should be used more often as a teaching strategy in mathematics lessons to foster students' mathematical skills. Furthermore, through the use of higher-level questioning, teachers can enable their students to make sense of, reason about, solve, predict and apply mathematics (Rowan \& Robles, 1998).

Several contradictory conclusions have been drawn by others regarding the effects of higher and lower level questions on students' achievement (Wilen, 1991). Conclusions given were; Lower-cognitive question being more effective in promoting student achievement (Rosenshine, 1976), no difference between the two types of questions and their impact on student achievement (Winne, 1979), teachers' use of higher-level questions led to greater student achievement (Redfield \& Rousseau, 1981), and Samson, Strykowski, Weinstein and Walberg (1987) concluded that there was little support for higher-level questioning enhancing student achievement. Gall and Rhody (1987) suggested that the reasons for the conflicting findings were that researchers used different definitions of higher-cognitive questions and different question classification scheme. They concluded by recommending teachers to use both lower- and higher-cognitive questions in their lessons. Teachers' use of lower-level questions will enable students to review basic facts and skills and higher level questions to develop students' critical thinking ability and skills.

The reports by Sadker and Sadker (1994) and Kelly (1988) which suggested that teachers asked boys more questions than they ask girls were true for US and Australian schools that the author had observed. In US, 30 male students were more engaged in teacher questions compared to only 21 female students. Whereas in Australia, the 'teacher question' ratio of male to female students was 2:1 (that is, $38: 19$ ). The overall results have shown that male students volunteered, and were called on more to teachers' questions compared to the female students. The data in this study suggest that gender biased teacher questioning do occur in the six Year 8 mathematics classes. Since teacher questions were mostly directed to male students in the mathematics classroom, thus, receiving more teacher attention, more teacher interaction and more feedback. Therefore, this will likely to cause an effect on the female students' class expectations and their achievements in mathematics (Becker, 1981). Flanders (1970) stated that teaching behaviour is the most potent, single, controllable factor that can alter learning opportunities in the classroom. It is important for teachers to recognise and understand that preconceived attitudes and expectations about boys and girls are likely to have an effect on children, particularly in the mathematics classroom (Wimer et al., 2001). 
US and Australian female students in this study should be included equally in classroom interactions and given equal encouragement in mathematics as their male classmates.

To be an effective teacher, responses from volunteering and non-volunteering students have to be balanced (Wilen \& Clegg, 1986) and, to be a vigilant teacher; one has to employ both higher-level and lower-level questions in the classrooms (Wimer et al., 2001). The Australian teacher from Australian school 1 (AU1) was observed to be the most vigilant teacher because she had employed both types of questioning (high-level and low-level questions) proportionately in her lesson and she is also considered as an effective teacher due to her distinctive use of balanced VA and SN.

A further analysis of the US and Australian data shows that teachers' allocation of wait time (Rowe 1978, 1986) was almost non-existent (average duration was one to two seconds). Wilen (1991) stated "Essential to student thinking, especially at the higher cognitive levels, is the amount of time a teacher allots for students reflection after asking a question and before a student responds, and immediately after the student responds before the teacher or another students reacts” (p. 20). It is important to stress to teachers that in order to get thoughtful responses from students and to generate active student participation, longer wait time should be enforced. All teachers observed in this study rewarded their students' answers with praises, for example, excellent, fantastic, very good, good job, and so on. Providing praises and acknowledgement is one of the criteria for effective questioning techniques that will increase student learning and fostering high achievement (Ellis, 1993; Rose \& Litcher, 1998; Shahrill, 2013).

There were similarities and differences observed from the US and Australian LPS video data. The striking similarity is the frequently asked low-level questions in the lessons. A study by Perry, Vanderstoep and Yu (1993) on questioning in first-grade mathematics classrooms in Japan, Taiwan and the United States, have found that teachers in Asian countries asked significantly more higher-level questions than the US teachers. It will be interesting to find out what the outcome will be for a study in comparing teacher questioning in secondary mathematics lessons in US and Australia with Asian countries. And also to conduct a further similar study to investigate the prevalence of teacher questioning (types, styles and gender) in mathematics lessons in Brunei Darussalam. Moreover, the findings that had been obtained from this study served as a baseline data for subsequent similar studies.

\section{Conclusion}

We reviewed the literature on teacher questioning strategies. In addition, we also analyzed and compared teacher questioning styles in US and Australian mathematics classes. The literature on Brunei Darussalam indicated that teacher questioning is often used during teaching. We recommend conducting a similar study based on Brunei to generate more information on this country.

\section{Limitations of the study}

In this study, only one lesson from each of the six schools, in two different countries were 
observed for the analyses of the collected data. It is essential to note that a teacher's practice cannot be characterized by a single lesson, and perhaps a more valid comparison would have been achieved if all ten video lessons from each country of the LPS data were observed. However, because of time constraint and problems in the accessibility of the available data, only six lessons were observed. Therefore due to these limitations, it is wise to treat the findings reported in this study as preliminary results of a baseline study of how teacher questioning can be depicted from two developed English speaking countries. Importantly, the results obtained and reported in this study may provide a similar or different scenario to a country such as Brunei Darussalam, where English is a second language but the language of instruction in schools is English. Another limitation of the present study is that we did not conduct any interviews to complement or supplement the secondary data embedded in the videotapes. Despite these limitations the findings may be valuable to mathematics teachers and the study therefore has practical significance.

\section{Acknowledgement}

The authors would like to express their gratitude to the following people in their kindness in allowing access to the LPS data set; Prof. D. Clarke, Prof. J. Lobato, Ms C. Mesiti, Dr. Seah L. H., Dr. Xu L. H., and staff members of ICCR.

\section{References}

Ainley, J. (2007). Using new technologies to investigate and improve learning: Trends and potentials (Keynote address). In A. W. A. Ghani, T. J. Sullivan, H. S. Dhindsa, A. Chamberlain, D. Boorer, K. Wood \& A. Baimba (Eds.), Changing contours of education: Future trends (pp. 13-24). Gadong: Universiti Brunei Darussalam.

Becker, J. (1981). Differential treatment of females and males in mathematics classrooms. Journal for Research in Mathematics Education, 12(1), 40-53. http://dx.doi.org/10.2307/748657

Boaler, J., \& Humphreys, C. (2005). Connecting mathematical ideas: Middle school video cases to support teaching and learning. Portsmouth, NH: Heinemann.

Bradshaw, L. \& Mundia, L. (2006). Attitudes to and concerns about inclusive education: Bruneian inservice and preservice teachers. International Journal of Special Education, 21(1), $35-41$.

Clarke, D. J. (2003). International comparative research in mathematics education. In A. Bishop, K. Clements, C. Keitel, J. Kilpatrick \& F. Leung (Eds.), Second International Handbook on Mathematics Education (pp. 145-186). Dordrecht, the Netherlands: Kluwer. http://dx.doi.org/10.1007/978-94-010-0273-8_6

Clarke, D. J., Emanuelsson, J., Jablonka, E., \& Mok, I. A. C. (Eds.). (2006a). Making connections: Comparing mathematics classrooms around the world. Rotterdam: Sense Publishers.

Clarke, D. J., Emanuelsson, J., Jablonka, E., \& Mok, I. A. C. (2006b). The learner’s 
perspective study and international comparisons of classroom practice. In D. J. Clarke, J. Emanuelsson, E. Jablonka \& I. A. C. Mok (Eds.), Making connections: Comparing mathematics classrooms around the world (pp. 1-22). Rotterdam: Sense Publishers.

Clarke, D. J., Keitel, C., \& Shimizu, Y. (Eds.). (2006). Mathematics classrooms in twelve countries: The insider's perspective. Rotterdam: Sense Publishers.

Ellis, K. (1993). Teacher questioning behavior and student learning: What research says to teachers. Albuquerque, NM: Paper presented at the Annual Meeting of the Western States Communication Association.

Flanders, N. A. (1970) Analyzing teacher behavior. Reading, MA: Addison-Wesley.

Fitzgerald, A., Hackling, M., \& Dawson, V. (2013). Through the viewfinder: Reflecting on the collection and analysis of classroom video data. International Journal of Qualitative Methods, 12, 52-64.

Gall, M. D., \& Rhody, T. (1987). Review of research on questioning techniques. In W. Wilen (Ed.), Questions, questioning techniques, and effective teaching (pp. 23-48). In Washington, D. C.: National Education Association.

Gould, C. (1995). High ability girls and the setting: Do teachers' interaction patterns change? Paper presented to the AAUW preconvention symposium, Orlando, FL.

Hamid, M. H. S., Shahrill, M., Matzin, R., Mahalle, S., \& Mundia, L. (2013). Barriers to mathematics achievement in Brunei secondary school students: Insights into the roles of mathematics anxiety, self-esteem, proactive coping, and test stress. International Education Studies, 6(11), 1-14. http://dx.doi.org/10.5539/ies.v6n11p1

Haq, F. S., \& Mundia, L. (2012). Comparison of Brunei pre-service student teachers’ attitudes to inclusive education and specific disabilities: Implications for teacher education. Journal of Educational Research, 105(5), 366-374. http://dx.doi.org/10.1080/00220671.2011.627399

Haq, F. S., \& Mundia, L. (2013). The assessment of psychological distress in Brunei female, mature age and part-time inservice student teachers: Counseling implications. European Journal of Educational Studies, 5(1), 87-100.

Hendrick, J., \& Stange, T. (1989). Do actions speak louder than words: An effect of the functional use of language on dominant sex role behavior in boys and girls. (Technical Report, 14, 1-29). Norman: University of Oklahoma, College of Education.

Hiebert, J., Gallimore, R., Garnier, H., Givvin, K. B., Hollingsworth, H., Jacobs, J., Chui, A., Wearne, D., Smith, M., Kersting, N., Manaster, A., Tseng, E., Etterbeek, W., Manaster, C., Gonzales, P., \& Stigler, J. (2003). Teaching mathematics in seven countries: Results from the TIMSS 1999 Video Study. Washington, DC: U.S. Department of Education, National Center for Education Statistics.

Jacobs, J., Garnier, H., Gallimore, R., Hollingsworth, H., Givvin, K. B., Rust, K., Kawanaka, T., Smith, M., Wearne, D., Manaster, A., Etterbeek, W., Hiebert, J., \& Stigler, J. (2003). Third 
International Mathematics and Science Study 1999 Video Study Technical Report: Volume 1: Mathematics. Washington, DC: U.S. Department of Education, National Center for Education Statistics.

Jacobs, J., Hollingsworth, H., \& Givvin, K. B. (2007). Video-based research made 'easy': Methodological lessons learned from the TIMSS video studies. Field Methods, 19(3), 284-299. http://dx.doi.org/10.1177/1525822X07302106

Kawanaka, T., \& Stigler, J. W. (1999). Teachers' use of questions in eighth-grade mathematics classrooms in Germany, Japan, and the United States. Mathematical Thinking and Learning, 1(4), 255-278. http://dx.doi.org/10.1207/s15327833mtl0104_1

Kelly, A. (1988). Gender differences in teacher-pupil interactions: A meta-analytic review. Research in Education, 9, 1-23.

Koizumi, Y. (2013). Similarities and differences in teachers' questioning in German and Japanese mathematics classrooms. ZDM The International Journal on Mathematics Education, 45, 47-59. http://dx.doi.org/10.1007/s11858-012-0482-2

Lincoln, Y. S. \& Guba, E. G. (1985). Naturalistic inquiry. Newbury Park, CA: Sage Publications.

Mahalle, S., Matzin, R., Hamid, M. H. S., Shahrill, M., \& Mundia, L. (2014). Brunei student teachers' selected personal attributes, attitudes to women and interpersonal trust: Brief psychological report. Asian Social Science, 10(1), 151-157. http://dx.doi.org/10.5539/ass.v10n1p151

Matzin, R., Shahrill, M., Mahalle, S., Hamid, M. H. S., \& Mundia, L. (2013). A Comparison of Learning Styles and Study Strategies Scores of Brunei Secondary School Students by Test Anxiety, Success Attributions, and Failure Attributions: Implications for Teaching At-risk and Vulnerable Students. Review of European Studies, 5(5), 119-127. http://dx.doi.org/10.5539/res.v5n5p119

Martino, A. M., \& Maher, C. A. (1994). Teacher questioning to stimulate justification and generalization in mathematics. New Orleans, LA: Paper presented at the Annual Meeting of the American Educational Research Association.

Mesiti, C., \& Clarke, D. (2003). Lesson Patterns in Superficially Similar Cultures: The USA and Australia. Paper presented as part of the symposium "Perspectives on International Comparisons of Lesson Structure in Mathematics Classrooms in Germany, Japan, the USA, and Australia" at the $10^{\text {th }}$ Biennial Conference of the European Association for Research on Learning and Instruction, Padova, Italy, August 26-30, 2003.

Mundia, L. (2012a). The Assessment of Mathematics Learning Difficulties in a Primary Grade 4 Child with High Support Needs: Mixed Methods Approach. International Electronic Journal of Elementary Education, 4(2), 347-366.

Mundia, L. (2012b). Policy changes in Brunei teacher education: Implications for the selection of trainee teachers. The Education Forum, 76(3), 326-342. 
http://dx.doi.org/10.1080/00131725.2012.682489

Mundia, L. (2012c). Assessment of GenNEXT learning outcomes at the University of Brunei Darussalam: A qualitative review of selected opportunities, benefits and challenges in human resource development. Journal of International Education and Leadership, 2(3), Fall 2012.

Mundia, L. (2010a). Problems in learning mathematics: Comparison of Brunei junior high school students in classes with and without repeaters. Journal of Mathematics Research, 2(3), 150-160.

Mundia, L. (2010b). Implementation of SPN21 curriculum in Brunei Darussalam: A review of selected implications on school assessment reforms. International Education Studies, 3(2), 119-129.

Mundia, L. (2010c). Brunei trainee teachers' coping strategies for stressful situations. International Journal of Psychological Studies, 2(1), 79-88.

Mundia, L. (2009). Implementation of inclusive education in Brunei Darussalam: Review of possible implications on school counsellors. Electronic Journal for Inclusive Education, Volume 2 Number 4. Spring / Summer 2009 Issue. Available online: http://www.cehs.wright.edu/ prenick/Spring_Summer09_Edition/spr_sum09.html

Mundia, L. (2007). Early childhood education in Swaziland and Brunei Darussalam: goals, achievements and challenges. Early Child Development and Care, 177(2), 151-158. http://dx.doi.org/10.1080/03004430500375885

Patton, M. Q. (1990). Qualitative evaluation and research methods. Newbury Park, CA: Sage Publications.

Perry, M., Vanderstoep, S., \& Yu, S. L. (1993). Asking questions in first-grade mathematics classes: Potential influences on mathematical thought. Journal of Educational Psychology, 85, 31-40. http://dx.doi.org/10.1037/0022-0663.85.1.31

Redfield, D. L., \& Rousseau, E. W. (1981). A meta-analysis of experimental research on teacher questioning behavior. Review of Educational Research, 51, 237-245. http://dx.doi.org/10.3102/00346543051002237

Rose, S., \& Litcher, J. (1998). Effective questioning techniques: In theory and practice. In L. P. McCoy (Ed.), Studies in Teaching 1998 Research Digest, (Research projects presented at Annual Research Forum, pp. 106-110) Wake Forest University, Winston- Salem, NC.

Rosenshine, B. (1976). Classroom instruction. In W. L. Gage (Ed.), The Psychology of teaching methods. Chicago: University of Chicago Press.

Rowan, T. E., \& Robles, J. (1998). Using questions to help children build mathematical power. Teaching Children Mathematics, 4, 504-509.

Rowe, M. B. (1974). Wait-time and rewards as instructional variables: Their influence on language, logic and fate control. Part 1. Journal of Research in Science Teaching, 11, 81-94. http://dx.doi.org/10.1002/tea.3660110202 
Rowe, M. B. (1978). Wait, wait, wait.... School Science and Mathematics, 78(3), 207-216. http://dx.doi.org/10.1111/j.1949-8594.1978.tb09348.x

Rowe, M. B. (1986). Wait time: slowing down may be a way of speeding up! Journal of Teacher Education, 43-49. http://dx.doi.org/10.1177/002248718603700110

Sadker, M., \& Sadker, D. (1994). Failing at fairness: How America's schools shortchange girls. New York: Scribner.

Samson, G. E., Strykowski, B., Weinstein, T., \& Walberg, H. J. (1987). The effects of teacher questioning levels on students' achievement. Journal of Educational Research, 80, 290-295.

Savola, L. T. (2008). Video-based analysis of mathematics classroom practice: Examples from Finland and Iceland. Unpublished doctoral dissertation, Columbia University.

Shahrill, M. (2013). Review of teacher questioning in mathematics classrooms. International Journal of Humanities and Social Science, 3(17), 224-231.

Shahrill, M. (2009). From the general to the particular: Connecting international classroom research to four classrooms in Brunei Darussalam. Unpublished doctoral dissertation, University of Melbourne.

Shahrill, M., \& Mundia, L. (2014). Coping Behavior of International Late Adolescent Students in Selected Australian Educational Institutions. Global Journal of Health Science, 6(1), 76-91. http://dx.doi.org/10.5539/gjhs.v6n1p76

Shahrill, M., Mahalle, S., Matzin, R., Hamid, M. H. Sheikh, \& Mundia, L. (2013). A Comparison of Learning Styles and Study Strategies used by Low and High Math Achieving Brunei Secondary School Students: Implications for Teaching. International Education Studies, 6(10), 39-46. http://dx.doi.org/10.5539/ies.v6n10p39

Shimizu, Y., Kaur, B., Huang, R., \& Clarke, D. (Eds.). (2010). Mathematical tasks in classrooms around the world. Rotterdam: Sense Publishers.

Stigler, J., Gonzales, P., Kawanaka, T., Knoll, S., \& Serrano, A. (1999). The TIMSS Videotape Classroom Study: Methods and findings from an exploratory research project on eighth-grade mathematics instruction in Germany, Japan, and the United States. Washington, DC: U.S. Department of Education, National Center for Education Statistics.

Suydam, M. N. (1985). Research report: Questions? Arithmetic Teacher, 32(6), 18.

Ulewicz, M., \& Beatty, A. (2001). The power of video technology in international comparative research in education. Washington, DC: National Academy Press.

Tait, K., \& Mundia, L (2014). A Comparison of Brunei and Hong Kong - SAR Student Teachers' Self-efficacy in Implementing Inclusive Education Practices: Implications for Teacher Education. Asian Social Science, 10(1), 51-60. http://dx.doi.org/10.5539/ass.v10n1p51

Tait, K., \& Mundia, L. (2012). Preparing teachers to meet the challenges of inclusive 
education in Negara Brunei Darussalam. In C. I. Forlin (Ed.), Future directions for inclusive teacher education: An international perspective (pp. 60-69).

Weimer, M. (1993). Improving your classroom teaching: Volume 1. Newbury Park, CA: Sage Publications.

Wilen, W. (1991). Questioning skills, for teachers. What research says to the teacher. Third edition. Washington DC: National Education Association. http://dx.doi.org/10.1080/00933104.1986.10505518

Wilen, W., \& Clegg, A. (1986). Effective questions and questioning: A research review. Theory and Research in Social Education, 14(2), 153-161.

Wilkinson, L. C., \& Martino, A. M. (1993). Students' disagreements during small-group mathematical problem solving. In R. B. Davis \& C. A. Maher (Eds.), Schools, Mathematics and the World of Reality (pp. 135-171). Needham Heights, Massachusetts: Allyn and Bacon.

Wimer, J. W., Ridenour, C. S., Thomas, K., \& Place, A. W. (2001). Higher order teacher questioning of boys and girls in elementary mathematics classrooms. Journal of Educational Research, 95(2), 84-92. http://dx.doi.org/10.1080/00220670109596576

Winne, P. H. (1979). Experiments Relating Teachers. Use of higher cognitive questions to student achievement. Review of Educational Research, 49, 13-50. http://dx.doi.org/10.3102/00346543049001013 